Ostapenko O. G. Candidate of Juridical Sciences, Associate Professor at the Department of Legal Regulation of the Economy Simon Kuznets Kharkiv National University of Economics Yerofyeyenko L. V. Candidate of Juridical Sciences, Associate Professor at the Department of Legal Regulation of the Economy Simon Kuznets Kharkiv National University of Economics

\title{
THE RIGHT TO ENTREPRENEURIAL ACTIVITY AND THE RIGHT TO WORK AS THE PRINCIPLES OF THE ECONOMIC SYSTEM AND NATIONAL ECONOMY OF UKRAINE
}

\section{Summary}

The work elucidates the problematic issues of constitutional and legal regulation of the right to entrepreneurial activity, its place in the system of constitutional economic rights and freedoms of human and citizen. The interrelation between the right to entrepreneurial activity with the right of property and the right to work is considered. The necessity of introduction of the system approach for legal regulation of bases of economic system at the constitutional level, and also maintenance of legal understanding and law enforcement of the right to entrepreneurial activity according to constitutional requirements is offered.

The article also analyzes the legislation governing the employment relationship of the employer - a natural person-entrepreneur - with employees. Gaps and shortcomings in the legislation on the concluding and terminating the employment contract have been identified. It is proposed to include in the provisions of the new Labor Code of Ukraine (hereinafter referred to as the LC) the possibility of concluding collective agreements in case if a natural person uses the labor of employees; to define the specific obligations of the employee and the employer in the employment contract; to provide for the expansion of the range of mutual rights and obligations of the parties, including the grounds for termination of the employment contract by agreement between the parties in the terms of the employment contract.

\section{Introduction}

The formation of Ukraine as a legal, social, democratic state with a developed civil society requires a balanced development and implementation of state economic policy, which will also ensure the appropriate level of socio-economic well-being of the population. Part 2 of Art. 3 of the 
Constitution of Ukraine [1] consolidates that human rights and freedoms and their guarantees determine the content and direction of the state, it is accountable to human for his or her activities, and the establishment and protection of human rights and freedoms is the main duty of the state. It is these principles that determine the democratic development of the Ukrainian statehood, require detailing this social direction of the relationship between the state and the man in the current legislation, ensuring their practical implementation by each person, but the Basic Law does not even contain the purpose of the economic system functioning.

The foundations of the constitutional order and the constitutional and legal status of human and citizen are among the most important institutions that require further research not only in the science of constitutional law, but also in relation to economics, such as constitutional economics [2].

In general, the issue of legal support for the development of the economic sphere of civil society and the right to entrepreneurship has been the subject of research by both Ukrainian and foreign scientists at the theoretical and brunch levels, in particular, M. Bondar, L. Voievodin, M. Vitruk, M. Koziubra, A. Kolodii, V. Kotiuk, M. Matuzov, M. Orzikh, P. Rabinovych, O. Petryshyn, N. Saniahmetova, O. Skrypniuk, M. Todyka, V. Ustymenko, O. Frytskyi and others. However, the issue of systematization of norms that determine the constitutional principles of the economic system of the Ukrainian state is still relevant.

It is the Constitution of Ukraine as the Basic Law of the state that determines the grounds of the economic system of Ukraine and serves as a legal basis for the legislative regulation of the national economy. Thus, among the principles of the grounds of the constitutional order, the principle of economic pluralism, consolidated in Art. 15 of the Basic Law, and which is further embodied in the provisions of Section II of the Constitution, in particular, by consolidating and guaranteeing property rights (Art. 41), the right to entrepreneurial activity (Art. 42) and the right to work (Art. 43), which together form the legal basis of a market economy [3]. In addition, a developed market economy, a variety of forms of property of the means of production, a high level of labor productivity, etc. are defined by legal science as economic guarantees of human rights and freedoms of a human and citizen.

Work is one of the sources of internal growth of human spiritual qualities, the basis of life and wealth of the society. It is work that is a human activity that requires mental and physical energy and creates material and spiritual values. Thanks to work, society exists, develops and improves.

\section{Part 1. The right to entrepreneurial activity as the basis of the economic system of Ukraine}

Consolidated in Art. 15 of the Constitution, the principle of economic diversity is the basis for the formation and development of the economic system of Ukraine, which is based on competitive principles and the absence 
of monopoly. This principle provides for the recognition of the existence, functioning and equal legal protection of all forms of property, and finds its further regulation in the provisions of the Civil Code of Ukraine (hereinafter referred to as the CC) [4] (in particular, in Articles 318, 319 of the CC).

The lack of systematic consolidation of the grounds of the economic system of the Ukrainian state should be considered problematic in the field of constitutional rule-making. However, the consolidation in the 1996 Constitution of the right to entrepreneurial activity was the impetus for the institutionalization of this element of a market economy. The Law of Ukraine «On Economic Independence of the Ukrainian SSR», which recognized individual (personal and private labor) property, became the legal basis for the adoption of the laws of Ukraine «On Property», «On Entrepreneurship», «On Enterprises in Ukraine», etc. In turn, these regulations formed the basis for consolidating in the Constitution of Ukraine the right of a person to entrepreneurial activity, which is a mandatory element of the system of economic human rights in the international legal practice of fixing human rights standards. Thus, the basic institutional principles of functioning of market economic relations have been established.

Further legal regulation of the right to entrepreneurial activity is carried out, first of all, in the provisions of the Civil and Economic Codes, which consolidate the freedom of entrepreneurship as a basis of civil law (Art. 3 of the $\mathrm{CC}$ ) and the principle of economic activity (Art. 6, Art. 43 of the Economic Code (hereinafter referred to as the EC)). In addition, these codified acts have special sections that systematically disclose certain aspects of the right to entrepreneurial activity (Chapter 4 of the EC and Chapter 5 of the CC). Thus, the provisions of the $\mathrm{CC}$ disclose the right of an individual to engage in entrepreneurial activity (Art. 50), civil liability of a natural person entrepreneur (Art. 52), and also contain reference rules for legal regulation of entrepreneurial activity of natural persons (Art. 51), bankruptcy of natural persons (Art. 53), etc. The norms of the EC [5] disclose the content of entrepreneurship (Art. 42), freedom of entrepreneurial activity (Art. 43), the principles of such activity (Art. 44), organizational and legal forms (Art. 45). However, restrictions on entrepreneurial activities are defined in Art. 4 of the Law of Ukraine «On Entrepreneurship» (repealed, except for this article).

We agree with the authors of the commentary to the Constitution of Ukraine, who have noted that Art. 42 of the Basic Law only states the right to entrepreneurial activity, but does not disclose its content. However, other related constitutional economic rights - the right to own, use and dispose of their property (Art. 41), the right to work (Art. 43) are formulated with a «clear definitive emphasis» [6, p. 309]. Thus, the constitutional consolidation of the right to entrepreneurship is mainly declarative in nature, and its content is set out in Art. 42 of the EC of Ukraine. Entrepreneurship is defined as an independent, proactive, systematic, economic activity at their own risk carried out by economic entities (entrepreneurs) in order to achieve economic and 
social results and make a profit. However, there are problems with the practical application of this rule. An administrative offense (Art. 164 of the Code of Administrative Offenses) [7], in particular, is the conduct of economic activity without state registration as an economic entity. In this aspect, the character of the systematic nature of such activities is important, but there is no quantification of this feature in any normative act. The Decree of the Cabinet of Ministers of Ukraine «On Fisheries Tax» dated March 17, 1997 stated: «If goods are sold more than four times during a calendar year, such activities are considered systematic and oblige citizens to register as economic entities in accordance with the current legislation of Ukraine» (Part 2 of Art. 5 of the Decree) [8]. This act expired on November 01, 2011; however, as practitioner lawyers point out with reference to the court decision, in 2017, the judges in determining the category of «systematic» have continued to refer to it [9].

Resolution of the Plenum of the Supreme Court of Ukraine No.3 dated April 25, 2003 «On the practice of application by courts of legislation on liability for certain crimes in the sphere of economic activity» (paragraph 4) clarifies that «Under the commission of a person not registered as a subject of entrepreneurship, any type of economic activity from among those subject to licensing, should be understood as the activity of an individual related to the production or sale of products, performance of works, provision of services for profit, which contains signs of entrepreneurial activity, i.e., carried out by a specified person directly independently, systematically (at least three times in one calendar year) and at his or her own risk» [10], but it is unclear on the basis of which rule the Plenum of the Supreme Court of Ukraine has provided a definition of regularity.

Thus, the Constitution of Ukraine only declaratively consolidates the right to entrepreneurship, the Economic Code provides its definition, but no normative act reveals its essential feature - regularity.

In addition to the interrelation of the right to entrepreneurial activity with other constitutional economic rights, its practical implementation is associated with all types of fundamental human and civil rights, in particular, social protection (Art. 46), strike (Art. 44), freedom of scientific and technical creativity, protection of intellectual property (Art. 54), etc. Entrepreneurship is closely related to property rights, as it involves the capitalization of tangible and intangible assets used in the manufacture and sale of products, works, services, and making a profit determines the acquisition of property of new things in civil or economic circulation. One of the principles of entrepreneurial activity is the free employment, which illustrates its interconnection with the right to work. Economic rights are also systematically linked to the constitutional obligation to pay taxes (Art. 67 of the Constitution of Ukraine).

In the context of regulating the basis of the economic system of the state, one should comprehensively investigate consolidated in the Basic Law, the 
right of every citizen to use natural objects of property of the people in accordance with the law, social orientation of the economy, prevention of property to the detriment of human and society (Art. 13, 41), freedom of movement and free choice of residence (Art. 33), equality of conditions for the development of all forms of property (Art. 116, paragraph 5), ensuring the protection of the rights of all subjects of property rights and management (Art. 55), competition in entrepreneurial activity, consumer rights (Art. 42), environmental safety and maintenance of ecological balance in Ukraine (Art. 16), proper, safe and healthy working conditions (Art. 43), mutually beneficial cooperation in foreign policy (Art. 18), the right to association (Art. 36), which, according to scientists, constitute a system of fundamental economic freedoms: those that determine the essence of status of economic freedom (material), and its institutional characteristics [11, p. 18-22], norms for the state to provide certain conditions are guarantees. Implementation of financial, price, investment and tax policy by the government (paragraph 3 of Art. 116 of the Constitution of Ukraine) as courses of economic policy through the system of state regulation of entrepreneurship actually creates different legal regimes of economic entities, really influencing their actual implementation [5, p. 311].

Accordingly, these norms are part of the system of constitutional and legal regulation of the general principles of the social order of the country, and the right to entrepreneurial activity is an element of legal economic order (defined by Art. 5 of the EC), which must correspond to the basic constitutional category «constitutional economic order». In the process of constitutional reform, a separate institution of «constitutional principles of the legal economic order in Ukraine» should be introduced in the Basic Law [5, p. 311-312]. For example, a number of constitutions of the European countries (Portugal, Italy, Spain, Lithuania, Poland, Croatia) contain separate sections on the basics of economic system or the constitutional economic order [12].

The right to entrepreneurial activity forms part of the system of relations of state regulation of macroeconomic processes, which largely limits the effect of the principle of freedom of entrepreneurial activity by its influence. Among the public law factors that establish the limits of the exercise of the right to entrepreneurial activity, the Constitution (Art. 42) defines only the imperatives of compliance with the rules of fair economic competition and consumer protection. However, such reservations do not cover all legal means of implementation of economic policy by the state, including through the mechanisms of state regulation of relations with the participation of entrepreneurs, which directly determine the real legal regime of entrepreneurship in Ukraine [5, p. 312].

The right to entrepreneurial activity is constitutionally formulated as a subjective right, and not an object of constitutional and legal regulation, and limits the subjective composition of the holders of such a subjective right only to 
natural persons. According to civil (Art. 83, 84 of the $\mathrm{CC}$ ) and economic legislation, subjects are also legal entities in various organizational and legal forms (Art. 45, 55 of the EC). Thus, legal entities remain outside the scope of direct constitutional and legal regulation [5, p. 313].

Article 42 of the Constitution contains a caveat that the sphere of realization of the right includes only those kinds of activity which are not forbidden by the law. However, it does not indicate the content of certain interests to ensure, which prohibitions can be legally applied. As the Basic Law does not contain references to the possibility of establishing restrictions on the right to entrepreneurship in the current legislation, it comes in a conflict with Art. 64 of this act on the impossibility of restricting the constitutional rights and freedoms of human and citizen, except as provided by the Constitution (imposition of martial law or state of emergency). In addition, the presence of a simple provision in the text of the Constitution on the possibility of prohibiting the right to do economic activity without reference to a certain public interest, the protection of which should be the basis for such prohibitions, practically leads to the possibility of uncontrolled restriction of current legislation [5, p. 313].

According to Part 2 of Art. 42 of the Constitution, the economic activity of deputies, officials, state authorities and local self-government bodies is limited by law. This rule is duplicated in Art. 43 of the EC, and such restrictions on the range of persons have a reference to current legislation. In this aspect, the opinion of S. Riznyk, who distinguishes between direct and indirect entrepreneurial activity, seems interesting. Under the first one, he understands entrepreneurship carried out by economic entities - natural persons and legal entities registered in the manner prescribed by law. Indirect is the entrepreneurial activity carried out by individuals through legal entities belonging to them on the right of private property. «From the point of view of constitutional law, a person who is the founder (participant) of the enterprise, taking an active part in the management of such enterprise, exercises his or her constitutional right to entrepreneurial activity, although is not a subject of the entrepreneurial activity in the sense of economic law» [13].

According to V. Kampo, issues of legal understanding (change not of the text of the Constitution, but creation of precedents and practices through the Constitutional Court of Ukraine, general courts, which form new models and mechanisms of market economy functioning) and law enforcement play an important role in forming a «nation of entrepreneurs» in Ukraine. He offers to the economy and entrepreneurs to understand the current constitutional mechanisms of the relevant sector of the economy, perhaps to conduct a kind of constitutional audit of its condition and long-term economic plans before resolving certain difficult questions on issues planning and developing of entrepreneurial activity in a certain branch. The scientist emphasizes the need to reduce administrative pressure on entrepreneurs, and most importantly, to ensure real equality of economic entities, real economic diversity and 
competition, in particular, to overcome the «prosperity» of oligarchic monopolies [14].

Thus, it is necessary to introduce a systematic approach to legitimizing the foundations of the economic system of the state through the constitutional and legal regulation of economic order by changing the method of normative provision of freedom of entrepreneurial activity and determining the subjective composition of this right.

\section{Part 2. Features of the employment relationship between the employer and a natural person-entrepreneur}

The construction of a national market economy in Ukraine has led to the development of entrepreneurship, including on the basis of private property without creating a legal entity. The authority of entrepreneurs who use hired labor for production purposes to make a profit has emerged and is gaining weight. A significant role in the national economic development of the country is played by the stability of the enterprises, the participants of which are the subjects of labor relations, namely the employer and employees.

Article 43 of the Constitution of Ukraine stipulates that every citizen has the right to work, including the opportunity to earn a living by work, which he or she freely chooses or freely agrees to. The Basic Law declares that the use of forced labor is prohibited. Everyone has the right to safe and healthy working conditions, to a salary not lower than the one prescribed by law. The Constitution of Ukraine prohibits the use of labor by women and minors in work that is dangerous and harmful to their health, and guarantees the protection of citizens from illegal dismissal. The right to timely obtaining of the reward for work is protected by law [1].

Everyone exercises his or her right to work through the conclusion of an employment contract with an enterprise, institution, organization or natural person, as well as in other forms specified by law.

One of the key roles in the formation of a market model of labor relations in Ukraine is played by the employer, whose activities are aimed at filling and improving labor relations with real content in accordance with current legislation. It is he or she who must create new vacancies, provide appropriate conditions for attracting hired labor, compliance with labor rights and social and labor guarantees of employees, participate in labor relations with the workforce, trade union and other participants.

Legal regulation of labor relations is aimed both at arranging the labor process of the employee and the conditions, under which this work should be used. One of these conditions is to determine the possibility of using by one person (employer) the work of another person, i.e., the problem of legal personality of the employer, his or her rights and responsibilities arising from the use of hired labor.

Back in the early 90s of the twentieth century in Ukraine, the legal literature has debated the concept and range of entities that can be recognized by 
employers. Previously, the LC used the term «enterprise, institution, organization» to denote a party who entered into an employment contract with an employee. The Law of the Ukrainian SSR dated March 20, 1991 «On Amendments to the Code of Labor Laws of the Ukrainian SSR in the Transition of the Republic to a Market Economy» replaced these terms with the phrase «owner of an enterprise, institution, organization or authorized body». Legislation did not legally define the meaning of this term, so in the legal literature the term «employer» started to be used [15].

Today, in Ukrainian legislation there are a number of characteristics of the concept of «employer». The employer as a subject of labor law, according to P. Pylypenko, is a person who provides work to another on the basis of an employment contract in the form of any of its varieties provided by law, including the election or appointment [16, p. 164].

The term «employer» was first legalized by the Law of Ukraine «On Protection of Rights to Inventions and Utility Models» of December 15, 1993, which states: «Employer is a person who hires an employee under an employment agreement (contract)». Later, the definition was duplicated in the Law «On protection of rights to the topography of integrated circuits» dated November 05, 1997 [17, p. 35].

The analysis of the provisions of the CC shows the need to specify the term «person», as Section II of this Act [4] defines persons as both natural and legal. But the nature of the employment relationship makes it impossible for a legal entity to participate in these relationships as an employee.

According to the Law of Ukraine «On Trade Unions, Their Rights and Guarantees of Activity», the employer is characterized as the owner of the enterprise, institution, organization, regardless of property, type of activity, industry or its authorized body (manager) or individual who uses hired labor in accordance with law.

According to the Law of Ukraine «On Employers' Organizations, Their Associations, Rights and Guarantees of Their Activities», the employer is a legal entity (enterprise, institution, organization) or a natural personentrepreneur who uses the work of natural persons within the employment relations.

In the definition proposed by O. Yaroshenko, «the employer is a natural person or legal entity, regardless of the form of property and organizational and legal form of creation, with which employees enter into employment relations established by employment agreement or contract» [18, p. 12]. This definition specifically indicates the range of persons who use hired labor on a contractual basis within the employment relations. A similar definition is contained in the Draft of the LC (Part 1 of Art. 22), where the «employer» is a legal entity (enterprise, institution, organization) or a natural person who uses the work of individuals within the employment relations [19]. 
This branching of the characteristics of the concept of «employer» in various legal acts leads to a number of issues of both legal and socioeconomic significance.

The legal status of the employer in labor law reflects his or her labor legal personality, which includes labor legal capacity, physical capacity, labor rights and responsibilities, as well as tort. All these elements arise simultaneously and turn into labor legal personality [20, p. 88].

Labor law regulates the work of employees. Thus, according to Part 2 of Art. 1 of the Law of Ukraine «On the Procedure for Resolving Collective Labor Disputes (Conflicts)» dated March 03, 1998, an employee is a natural person who works under an employment contract at an enterprise, institution and organization, in their associations or with natural persons, who use hired labor [21].

Thus, a natural person-entrepreneur (hereinafter referred to as a selfemployed person) who uses hired labor is a subject of labor law.

Officially, at the legislative level, a natural person as an employer was legalized by the Law of Ukraine "On Amendments to the Labor Code of Ukraine» [22] dated July 05, 1995, where in Art. 21 a natural person was recognized as a party to the employment contract, as well as the owner of the enterprise, institution, organization or its authorized body. Art. 7 of the LC stipulated that the peculiarities of labor regulation of persons working for natural persons under employment contracts were established by law [23].

Recognizing the right of a natural person to act as an employer, the LC does not name the requirements for him to acquire labor legal personality. Therefore, applying the provisions of the CC (Art. 9), we can assume that such a person is a person who has full civil capacity [23].

The legal status of a natural person-entrepreneur is consolidated in labor law at the position of the person, which is expressed in the recognition of the state as a subject of labor law, determining the range of basic, inalienable rights and responsibilities it has in connection with the use of labor of other people hired. The labor employer's legal personality of a natural person determines the limits of this status, and the statutory rights and obligations determine its content [24].

We agree with the opinion of T. Zanfirova proposed in her study, where it is noted that «considering the legal status of the employer - a natural person in the field of labor law, we assume that specific features inherent as an employer are in the field of sectoral legal status, and its boundaries are defined by the sectoral labor employer legal personality... Recognizing a person as a legal entity in relation to the range of sectoral statutory rights and responsibilities and participation in social and labor relations, the state sets criteria for determining its ability to a particular activity, in our case, to provide work defined by the employment contract to other persons... Therefore, the ability to be a participant in labor relations as an employer for a natural person who is not engaged in entrepreneurship depends only on the 
acquisition of sectoral employer legal personality. For a person engaged in entrepreneurial activity, it is crucial to register him in the prescribed manner as an economic entity in the manner prescribed by law. The above within the sectoral employer status of an individual allows to distinguish the special status of the entrepreneur - the employer, whose activities are aimed at making a profit and who uses hired labor to achieve this goal» [24].

Since the employer is a legal entity (enterprise, institution, organization) or a natural person-entrepreneur who uses the work of individuals within the labor relations (Part 1 of Art. 1 of the Law of Ukraine «On employers' organizations, their associations, rights and guarantees of their activity» dated June 22, 2012), the natural persons-entrepreneurs must comply with all the requirements set by $\mathrm{LC}$, in the case of hiring employees [25].

According to Art. 21 of the LC «Employment contract is an agreement between an employee and the owner of an enterprise, institution, organization or its authorized body or a natural person, under which the employee undertakes to perform the work specified in this agreement, subject to internal labor regulations, and the owner of the enterprise, institution, the organization or the authorized body or a natural person undertakes to pay the employee wages and provide working conditions necessary for the performance of work provided for by labor legislation, collective agreement and agreement of the parties» [23]. When concluding an employment contract with a natural person who uses hired labor, the compliance with the written form is a mandatory condition, and its form is approved by the order of the Ministry of Labor of Ukraine No. 260 dated June 8, 2001 [26].

Each employment contract has certain mandatory conditions, without which the contract cannot be considered valid. These include such conditions: the employment of a citizen and the place of work; about the labor function; about the size of the employee's salary; about the time of the beginning of work (in case of the conclusion of the fixed-term employment contract, term of the termination of work) [27].

The agreement of the parties determines the place of work of the employee, ie a particular enterprise, institution, organization located in a certain area (settlement), where the employee will perform the work stipulated by the employment contract. The parties to the employment contract may also determine the employee's workplace (subdivision, department, shop, site, specific mechanism, unit, etc.). The workplace can be defined quite specifically.

Another necessary condition of the employment contract is the condition of the type of work, which is determined by the agreement of the parties or, as it is called, the employment function of the employee. The latter is characterized by a combination of subjective factors: profession, specialty, qualification, and objective factors: the relevant position or work performed. Labor function is a type of work or a position, the performance or 
replacement of which is possible regarding the profession, specialty, and qualification of the employee [27].

An important condition of the employment contract is to determine the level of wages of the employee, which is determined by the parties of the contract, but not lower than the minimum level established by the legislation of Ukraine [27].

An essential condition that must be reflected in the employment contract is also the date of conclusion and term of the contract. The date of conclusion is indicated directly in it and indicates the time of the official beginning of the employment relationship between the employer and the employee [27].

In the scientific literature, the opinion was expressed that an employment contract with a natural person is concluded for an indefinite period. Based on the requirements of Art. 23 of the Labor Code, the contract may be concluded for a certain period, as evidenced by the practice of concluding such employment contracts. Therefore, the employment contract with the employer - a natural person may be indefinite or fixed-term [28].

The employer is obliged to comply with all the guarantees provided by law for employees: not to exceed the established by Art. 50 of the LC norm of working hours that is 40 hours per week; to guarantee reduced working hours, time on the eve of weekends and holidays; wages must be not less than the minimum wage; to provide days off and paid annual vacation lasting at least 24 calendar days [29, p. 166].

However, there are a number of issues that labor law does not take into account in the relations between a natural person employer and an employee. This may include giving the employee the opportunity to live at the employer's place of residence, for example, for a person doing housework, caring for children, security, and so on. In some cases, the scope of the employee's responsibilities may be expanded due to the fact that in addition to working during the employer's entrepreneurial activities, the employee may also accept certain obligations in the field of service work in the personal household. The definition of specific obligations of the employee and the employer in the employment contract should contribute in this case to the real protection of their interests and the protection of subjective rights that constitute the content of the individual employment relationship. This applies to the problem of protection of trade secrets, as well as information on the personal life of the employer, ensuring its commercial interests $[24 ; 30]$.

In addition to these basic conditions, the employment contract may specify optional (additional) conditions. Their absence does not indicate the incomplete content of the employment contract. But when the parties wish to establish and include them in the employment contract, they are binding for the parties, that they do not contradict the law and regulations [27].

The main problem that arises when determining the content of additional (optional) terms of the employment contract is the issue of ensuring the actual implementation of non-commitments. The literature quite rightly draws 
attention to the imperfection of labor legislation in this matter. Thus, the authors of the scientific and practical commentary on the labor legislation of Ukraine point out that, unlike civil law, labor law does not provide any system for ensuring the fulfillment of obligations arising from the optional conditions. Moreover, it is not always possible to judicially protect the interests of the employee, for example, in the case of failure to rent or own an apartment $[27 ; 31]$.

When concluding an employment contract, the employer has no right to hide working conditions that worsen the position of employees compared to the legislation of Ukraine on labor [27].

In connection with the removal from the LC of Art. 241, starting from January 01,2015 , there is no requirement for registration of an employment contract concluded by a natural person-entrepreneur with an employee in the employment service. Therefore, from the mentioned date, the bylaws developed for the implementation of this article have no force.

Thus, from 2015, when registering an employment relations with an employee, the entrepreneur is not obliged to register the employment contract with the employment center, but must notify the State Fiscal Service (hereinafter referred to as the SFS) of the new employee. Without such notification of the SFS on hiring, an employee cannot be allowed to work.

Also, no changes have been made to the Instruction on the procedure for keeping employment records of employees, approved by the order of the Ministry of Justice, Ministry of Labor, Ministry of Social Protection No. 58 dated the July 29, 1993 (hereinafter referred to as the Instruction No. 58), on the grounds for making entries in the employment record [25]. According to the requirements of Part 2 of Art. 24 of LC, when concluding an employment contract, a citizen is obliged to submit an employment record book to the employer. Article 48 of the LC stipulates that in accordance with paragraph $2.21^{1}$ of the Instruction No. 58 employment records of employees working in a private individual are stored directly with the employees themselves. As the employment center no longer registers employment contracts, only the entrepreneur records the admission and dismissal in the employment record book.

It should be noted that if the entrepreneur does not have a seal, it does not prevent him or her from making entries in the employment record of the employee. Article $58^{1}$ of the EC abolishes the obligation of economic entities to have a seal, i.e., its presence is not mandatory. An entrepreneur who works without a seal certifies all records with his or her signature [5].

With regard to the documents to be provided in the case of hiring an employee to a natural person-entrepreneur, the State Enterprise in letters No. 1751 dated February 18, 2011 and February 24, 2011 No. 1875 explains that the relations of the economic entity and employees are regulated by labor legislation [25]. 
According to Part 2 of Art. 24 of the LC during the conclusion of the employment contract the citizen is obliged to submit a passport or other identity document, employment record book, and in cases provided by law, also a document on education (specialty, qualification), health status and other documents [23].

Table 5 of Annex 4 to the Procedure for forming and submitting by insurers a report on the amounts of accrued single contribution to compulsory state social insurance, approved by the order of the Ministry of Revenue and Duties of Ukraine No. 454 dated September 09, 2013, (hereinafter referred to as the Procedure), is intended for registration of insured persons in the register of insured persons and given that table 5 is submitted by the insurer, if during the reporting period was, in particular: concluded or terminated an employment contract (civil contract, except for civil contract concluded with a natural person-entrepreneur, if the performed work (provided services) correspond to the types of activity specified in the extract from the Unified State Register of Legal Entities and Individual Entrepreneurs), with the insured person [32].

Therefore, the labor legislation requires the employer to notify the SFS about the hiring of employees by submitting Table 5 of Form No.D4 as part of the monthly reporting on SRS.

Analyzing labor legislation, namely Art. 11 of the current LC and the provisions of Art. 2 of the Law of Ukraine «On Collective Bargaining Agreements», which does not provide for the possibility of concluding a collective agreement with the participation of a natural person employer, the imperfection of current labor legislation on this issue is seen [24].

There is a necessity to propose to include in the new L provisions, which consolidate the possibility of concluding collective agreements in the case of usage by a natural person the labor of hired employees. These are cases when, as a result of a significant number of employees, a labor collective with its own collective rights is formed. Such rights are formed according to the degree of formation of the interests of a community or group. O. Protsevskyi identifies the following features. Firstly, they embody the «human dimension», although collective rights are not a set of individual rights of the persons who make up the collective; secondly, they can be carried out not by an individual, but by a team, a community [24;33].

Since the employment relationship between a self-employed person and an employee is regulated by current labor legislation, the termination of the employment contract is regulated in accordance with the grounds specified in Art. 36 of the LC.

According to paragraph 4 of the Resolution of the Cabinet of Ministers of Ukraine «Some issues of application of labor legislation by an individual who uses hired labor» No. 1168 dated October 29, 2009 if the self-employed person wants to dismiss an employee (without his presence) on his own initiative in cases, defined by the LC, the self-employed person is obliged to 
notify the employee in writing of his intention and within the specified time to make the calculation provided by law. In case of death of the employer - selfemployed person, the employment contract is withdrawn from registration «in connection with the death of the employer» on the basis of documents confirming the death, taking into account the provisions of the Procedure No. 260 [26]. Given that one of the parties is not present to make a record of dismissal in accordance with paragraph $2.21^{1}$ of the Instruction No. 58, and the employment center authority does not have powers to make such a record, but in practice the official makes an entry in the employee's employment record on the registration of the relevant employment contract in connection with the death of the employer and certifies it in the prescribed manner [34].

As T. Zanfirova notes in her study, «a separate problem that requires special consideration is the need to allow natural persons to agree in the employment contract on the grounds for its termination» [23]. Agreeing with this opinion, we propose to include in the new LC a rule that would regulate the agreement between natural persons to include in the employment contract grounds for its termination, and in the absence of an agreement, to apply the rules of this Code. When including additional grounds for termination in the employment contract, it is necessary they be formulated as clearly and specifically as possible, so that there are no misunderstandings and different interpretations in their application. These grounds must be determined both by the specifics of the employer's activity and the position of the employee, the scope of his responsibilities and may not encroach on personal freedom, citizens' rights and contradict the purposes of using someone else's work [23].

\section{Conclusions}

The constitutional and legal consolidation of basic economic rights and freedoms of human and citizen has determined the institutional foundations for the functioning of market economic relations. Regulation and guarantee by the Basic Law of property rights (Art. 41), the right to entrepreneurial activity (Art. 42) and the right to work (Art. 43) determine the legal basis of the market economy of the Ukrainian state.

However, consolidating only the social orientation of the state requires improving the provisions of Section I of the Constitution by systematizing the norms that determine the constitutional principles of the economic system of the Ukrainian state and form at least the purpose of such a system.

The Constitution of Ukraine only declaratively consolidates the right to entrepreneurship, the Economic Code provides its definition, but no normative act reveals its essential feature which is regularity. Therefore, it is necessary to comprehensively ensure the formation of the constitutional and legal institution of the right to entrepreneurial activity at the level of laws and bylaws by eliminating gaps in the legal regulation of its key features.

Foreign positive experience of legal regulation of the right to entrepreneurial activity as an element of the legal economic order (defined by 
Art. 5 of the Economic Code), allows us to talk about the need to define the constitutional and legal category of «constitutional economic order». And in the process of constitutional reform, a separate institution of «constitutional principles of the legal economic order in Ukraine» should be introduced in the Basic Law.

Since the Constitution limits the subjective composition of holders of the right to entrepreneurial activity only to legal entities, it is not defined the limit of prohibitions on the exercise of the right to entrepreneurship, the provisions of the Basic Law in this aspect need further improvement.

In addition, it is necessary to propose to include in the new Labor Code of Ukraine provisions that consolidate the possibility of concluding collective agreements in the event of an individual using the labor of employees.

To ensure the interests and protect the subjective rights, that make up the content of the individual employment relationship, it is necessary to define in the employment contract the specific obligations of the employee and the employer.

It is necessary to include in the new Labor Code of Ukraine a provision on the provisions of the employment contract to expand the range of mutual rights and obligations of the parties, including the grounds in case of termination of the employment contract by agreement between its parties.

For the proper functioning of a market economy in Ukraine, in addition to improving the law-making process in the field of systemic constitutional regulation of the economic system of the state, it is necessary to ensure the necessary level of law enforcement and understanding of these basic principles and requirements of real equality, economic diversity and competition in Ukraine, also by improving the general legal culture of the people.

\section{References:}

1. Konstytucija Ukrajiny (1996) [Constitution of Ukraine]. Vidomosti Verkhovnoji Rady Ukrajiny. no 30. Art. 141.

2. Kemenjash R.Ju. (2015) Konstytucijne fiksuvannja ekonomichnoji sfery, ekonomichna konstytucija chy konstytucijna ekonomika jak sfera efektyvnogho funkcionuvannja [Constitutional fixation of the economic sphere, economic constitution or constitutional economy as a sphere of effective functioning]. Pravo $i$ suspiljstvo, no 5-2, pp. 3-6.

3. Ishhuk S. I. (2018) Okremi konstytucijno-pravovi zasady funkcionuvannja ghromadjansjkogho suspiljstva v Ukrajini: svoboda pidpryjemnycjkoji dijaljnosti [Some constitutional and legal principles of civil society in Ukraine: freedom of entrepreneurial activity]. Journal «ScienceRise: Juridical Science». no 1(3), pp. 11-17. Available at: https://core.ac.uk/reader/288841142 (accessed 25 June 2020).

4. Cyviljnyj kodeks Ukrajiny (2003) [Civil Code of Ukraine] (official website of the Verkhovna Rada of Ukraine). Available at: https://zakon.rada.gov.ua/laws/show/43515\#Text (accessed 25 June 2020). 
5. Ghospodarsjkyj kodeks Ukrajiny (2003) [Economic Code of Ukraine] (official website of the Verkhovna Rada of Ukraine). Available at: https://zakon.rada.gov.ua/ laws/show/436-15\#Text (accessed 25 June 2020).

6. Tacij V. Ja. (2011) Konstytucija Ukrajiny. Naukovo-praktychnyj komentar [Constitution of Ukraine. Scientific and practical commentary]. Kharkiv: Pravo. (in Ukrainian)

7. Kodeks Ukrajiny pro administratyvni pravoporushennja (1984) [Code of Administrative Offenses of Ukraine] (official website of the Verkhovna Rada of Ukraine). Available at: https://zakon.rada.gov.ua/laws/show/80731-10\#Text (accessed 23 June 2020).

8. Pro podatok na promysel: Dekret Kabinetu Ministriv Ukrajiny (1993) [On Fisheries Tax: Decree of the Cabinet of Ministers of Ukraine] (official website of the Verkhovna Rada of Ukraine). Available at: https://zakon.rada.gov.ua/laws/show/24-93\#Text (accessed 23 June 2020).

9. Piddubko Je. Systematychnistj jak skladova pidpryjemnyctva [Systematic as a component of entrepreneurship]. Ligha.Bloghy (electronic resource). Available at: https://blog.liga.net/user/epoddubko/article/27274 (accessed 23 June 2020).

10. Pro praktyku zastosuvannja sudamy zakonodavstva pro vidpovidaljnistj za okremi zlochyny u sferi ghospodarsjkoji dijaljnosti: Postanova Plenumu Verkhovnogho Sudu Ukrajiny (2003) [On the practice of application by courts of legislation on liability for certain crimes in the sphere of economic activity: Resolution of the Plenum of the Supreme Court of Ukraine] (official website of the Verkhovna Rada of Ukraine). Available at: https://zakon.rada.gov.ua/laws/show/va003700-03\#Text (accessed 23 June 2020).

11. Ustymenko V. A. (2011) Konstytucijni zasady ekonomichnoji systemy Ukrajiny: Monoghrafija [Constitutional principles of the economic system of Ukraine]. Donecjk: Jugho-Vostok. (in Ukrainian)

12. Okunjkov L. A. (1997) Konstytucyy ghosudarstv Evropejskogho Sojuza [Constitutions of the states of the European Union]. Moscow: YNFRAMNORMA.

13. Riznyk S. V. (2008) Zabezpechennja derzhavoju konstytucijnogho prava ljudyny $i$ ghromadjanyna na pidpryjemnycjku dijaljnistj [Ensuring by the state of the constitutional right of a person and a citizen to entrepreneurial activity] (PhD Thesis), Kyjiv: Kyjiv. nac. un-t vnutr. sprav.

14. Kampo V. (2020) Konstytucija Ukrajiny ta formuvannja naciji pidpryjemciv [The Constitution of Ukraine and the formation of a nation of entrepreneurs] (electronic journal). no 5(711). Available at: https://yur-gazeta.com/publications/ practice/konstytutsiine-pravo/konstituciya-ukrayini-ta-formuvannya-naciyi-pidpriemciv.html (accessed 23 June 2020).

15. Alekseev S.S. (1994) Teoryja prava [Theory of law]. Moscow: BEK (in Russian)

16. Pylypenko P.D. (1999) Problemy teoriji trudovogho prava. Monoghrafija [Problems of the theory of labor law]. Lviv: Vydavn. centr Ljviv. Nacionaljnogho un-tu imeni I. Franka.

17. Sereda O. Gh. (2012) Pravovyj status robotodavcja za proektom Trudovogho kodeksu Ukrajiny [Legal status of the employer under the draft Labor Code of Ukraine]. Jurydychnyj chasopys Nacionaljnoji akademiji vnutrishnikh sprav, no 1(3), pp. 35-41.

18. Jaroshenko O.M. Pravovyj status storin trudovykh vidnosyn [Legal status of the parties to the employment relationship] (PhD Thesis): Kharkiv: NJuAU im. Jaroslava Mudrogho.

19. Trudovyj kodeks Ukrajiny (2014) [Labor Code of Ukraine]. Projekt. Available at: http://search.ligazakon.ua/l_doc2.nsf/link1/DH1A200V.html (accessed 15 June 2020).

20. Kostjuk V. L. (2010) Problemy pravovogho stanovyshha robotodavcja za KZpP Ukrajiny ta proektu trudovogho kodeksu Ukrajiny [Problems of the legal status of the employer under the Labor Code of Ukraine and the draft labor code of Ukraine]. Naukovi zapysky. Jurydychni nauky, vol. 90, pp. 87-90. 
21. Rymar I. A. (2010) Osoblyvosti pravovogho statusu pracivnyka i robotodavcja jak sub'jektiv indyvidualjnykh pravovidnosyn [Features of the legal status of the employee and the employer as subjects of individual legal relations]. Aktualjni problemy derzhavy i prava, no 20, pp. 119-125.

22. Pro vnesennja zmin i dopovnenj do Kodeksu zakoniv pro pracju Ukrajiny (1995): Zakon Ukrajiny [On Amendments and Addenda to the Labor Code of Ukraine] Vidomosti Verkhovnoji Rady Ukrajiny, no 28, Art. 204.

23. Kodeks zakoniv pro pracju Ukrajiny (1971) [Labor Code of Ukraine] (official website of the Verkhovna Rada of Ukraine). Available at: http://zakon2.rada.gov.ua/ laws/show/322-08 (accessed 16 June 2020).

24. Zanfirova T. A. (2004) Pravove reghuljuvannja trudovykh vidnosyn za uchastju robotodavcja - fizychnoji osoby [Legal regulation of labor relations with the participation of the employer - an individual] (PhD Thesis), Kharkiv: NJuAU im. Jaroslava Mudrogho.

25. Jak pidpryjemcju u 2015 roci oformyty na robotu (na osnovne misce) pracivnyka? [How can an entrepreneur hire an employee in 2015 (for the main position)?]. Available at: http://olexrda.kr-admin.gov.ua/yak-pidpriyemtsyu-u-2015-rotsi-oformiti-na-robotu-naosnovne-mistse-pratsivnika/ (accessed 16 June 2020).

26. Pro zatverdzhennja Formy trudovogho doghovoru mizh pracivnykom i fizychnoju osoboju, jaka vykorystovuje najmanu pracju (2001): Minpraci Ukrajiny; Nakaz, Forma, Porjadok [On approval of the Form of employment contract between an employee and an individual who uses hired labor] (official website of the Verkhovna Rada of Ukraine). Available at: http://zakon4.rada.gov.ua/ laws/show/z0554-01 (accessed 16 June 2020).

27. Vasyljko I. V. (2014) Porjadok ta osoblyvosti ukladennja trudovykh doghovoriv mizh pracivnykam i robotodavcem-fizychnoju osoboju [The order and features of the conclusion of employment contracts between employees and the employer-individual]. Naukovyj visnyk Khersonsjkogho derzhavnogho universytetu, no 5-2, vol. 3, pp. 79-81.

28. Zadorozhnyj S., Nabojchenko R. (2013) Trudovyj doghovir z robotodavcem fizychnoju-osoboju [Employment contract with an individual employer] Proceedings of the XVIII Mezhdunarodnaja nauchno-praktycheskaja ynternet-konferencyja "Problemy y perspektyvy razvytyja nauky $v$ nachale tretj'egho tysjacheletyja $v$ stranakh SNGh» (Ukraine, Perejaslav-Khmeljnycjkyj, December 29-30, 2013). Available at: http://oldconf.neasmo.org.ua/node/273 (accessed 16 June 2020).

29. Bolotina N. B. (2008) Trudove pravo Ukrajiny: Pidruchnyk [Labor law of Ukraine]. Kyjiv: Znannja.

30. Pylypenko P. D. (2003) Pidstavy vynyknennja indyvidualjnykh trudovykh pravovidnosyn. Monoghrafija [Grounds for the emergence of individual labor relations]. Kyjiv: Znannja.

31. Stychynsjkyj B. S., Zub I. V., Rotanj V. Gh. (2003) Naukovo-praktychnyj komentar do zakonodavstva Ukrajiny pro pracju / [Scientific and practical commentary on the legislation of Ukraine on labor]. Kyjiv: A.S.K.

32. Pro orghanizaciju roboty (2015): Lyst Derzhavnoji fiskaljnoji sluzhby Ukrajiny [On the organization of work] (official website of the State Fiscal Service of Ukraine) Available at: http://sfs.gov.ua/zakonodavstvo/ediniy-vnesok-na-zagalnoobovyazkove-/listi/ print-63512.html (accessed 16 June 2020).

33. Procevsjkyj O. I. (2001) Pro predmet trudovogho prava Ukrajiny [On the subject of labor law of Ukraine]. Pravo Ukrajiny, no 12, p. 81.

34. Instrukcija pro porjadok vedennja trudovykh knyzhok pracivnykiv (1993): zatv. nakazom M-va Praci Ukrajiny, M-va Justyciji Ukrajiny, M-va soc. zakhystu naselennja [Instruction on the procedure for keeping employment records of employees] (official website of the Verkhovna Rada of Ukraine). Available at: http://zakon2.rada.gov.ua/laws/show/z0110-93/print (accessed 16 June 2020). 